\section{'Harmonie' Strawberry}

Shahrokh Khanizadeh, ${ }^{1}$ Martine Deschênes, Audrey Levasseur, Odile Carisse, Marie Thérèse Charles, and Djamila Rekika

Agriculture and Agri-Food Canada, Horticultural Research and Development Centre, 430 Gouin Boulevard, St-Jean-sur-Richelieu, QC, Canada J3B 3E6

Rong Tsao and Raymond Yang

Agriculture and Agri-Food Canada, Food Research Centre, 93 Stone Road West, Guelph, Ontario, Canada N1G 5C9

Jennifer DeEll

Ontario Ministry of Agriculture and Food, Box 587, 1283 Blueline Road and Highway \#3, Simcoe, ON, Canada N3Y 4N5

\section{Patrice Thibeault}

L'Association des producteurs de fraises et framboises du Québec, 555 Boulevard Roland-Therrien, Longueuil,QC, Canada J4H 3 Y9

\section{Jean-Pierre Privé}

Agriculture and Agri-Food Canada, Food and Horticulture Research Centre, Senator Hervé J. Michaud Research Farm, 1045 St. Joseph Road Bouctouche, $N B$, Canada

\section{Campbell Davidson}

Agriculture and Agri-Food Canada, Cereal Research Centre, Unit 100-101 Route 100 Morden, MB, Canada R6M 1 Y5

\section{Bob Bors}

University of Saskatchewan, Plant Sciences, 51 Campus Drive, Saskatoon Saskatchewan, Canada S7N $5 A 8$

Additional index words. Fragaria $\times$ ananassa, fruit breeding, storage, shelf life, red stele
Hervé J. Michaud Research Farm, Bouctouche, (longitude 64.44W, latitude $46.28 \mathrm{~N}$ ), $\mathrm{NB}$, and the Cereal Research Centre, Morden (longitude $98.06 \mathrm{~W}$, latitude $49.11 \mathrm{~N}), \mathrm{MB}$, as well as in Vineland (longitude 79.24W, latitude $43.10 \mathrm{~N}$ ), Ontario. 'Harmonie' is also being tested in Europe by Meiosis (Bradbourne House, Stable Block, East Malling, Kent ME19 6DZ).

\section{Description and Performance}

Plants of 'Harmonie' are of medium vigor, have a flat growing habit, and produce approximately five inflorescences per crown. Flowers are perfect. Plants can tolerate winter air temperatures of up to $-30{ }^{\circ} \mathrm{C}$ with $10 \mathrm{~cm}$ straw mulch cover. Petioles are short with three, medium green, cupped and obtuse leaflets, with slightly acute teeth. The terminal leaflets have a 1.25 length to width ratio.

'Harmonie' is moderately susceptible to leaf spot (Mycosphaerella fragariae(Tul.) Lindau) and physiological leaf scorch (Diplocarpon earlina Ell. \& Ev.). No symptoms of powdery mildew (Sphaerotheca macularis (Wallr.:Fr.) Lind.) or gray mold (Botrytis cinerea Pers.: Fr.) have been noted since 1999.

'Harmonie' produces attractive large, red, shiny fruit (Fig. 1). The fruit shape is globoseconic. Theflesh is orange-red almost throughout and is firm. Fresh fruit store well for up to 3 to 4 days at room temperature and longer under refrigerated storage conditions (Table 2).

Annual crop yields of 'Harmonie' are similar to 'Kent', 'Bounty' and 'Chambly', but lower than 'Joliette', 'Jewel', 'Veestar',

'Harmonie' is a new June-bearing strawberry cultivar (Fragaria $\times$ ananassa Duch.), developed for Eastern Central Canada and other similar cold climates. 'Harmonie' has very attractive light red glossy fruit, which is very firm and have a shelf life of several days. 'Harmonie' is suitable for pick your own, fresh market and shipping (Fig. 1).

\title{
Origin
}

'Harmonie', tested as APF9323-3, is a progeny resulting from a cross between 'Yamaska' and 'Joliette' made in 1993 by S. Khanizadeh (Fig. 2). 'Harmonie' has been tested at the Agriculture and Agri-Food Canada (AAFC) sub-station in L'Acadie (longitude $73.35 \mathrm{~W}$; latitude $45.32 \mathrm{~N}$ ), Quebec since 1994, and during 1995-2002 by our partners Association des Producteurs de Fraises et Framboises du Québec (APFFQ) and Réseau d'Essais de Petits Fruit, CPVQ (Quebec Regional small fruit trials, Conseil des Productions Végétales du Québec) in Ile d'Orléans (longitude 71.00W, latitude $46.57 \mathrm{~N}$ ), Quebec. It has been also tested by otherAAFC research centers (Atlantic Food and Horticulture Research Centre, Senator

Received for publication 8 Apr. 2004. Accepted for publication 3 Sept. 2004. Agriculture and Agri-Food Canada, St-Jean-sur-Richelieu contribution.

${ }^{1}$ To whom reprint requests should be addressed; e-mailkhanizadehs@agr.gc.ca,www.pgris.com/ harmonie.

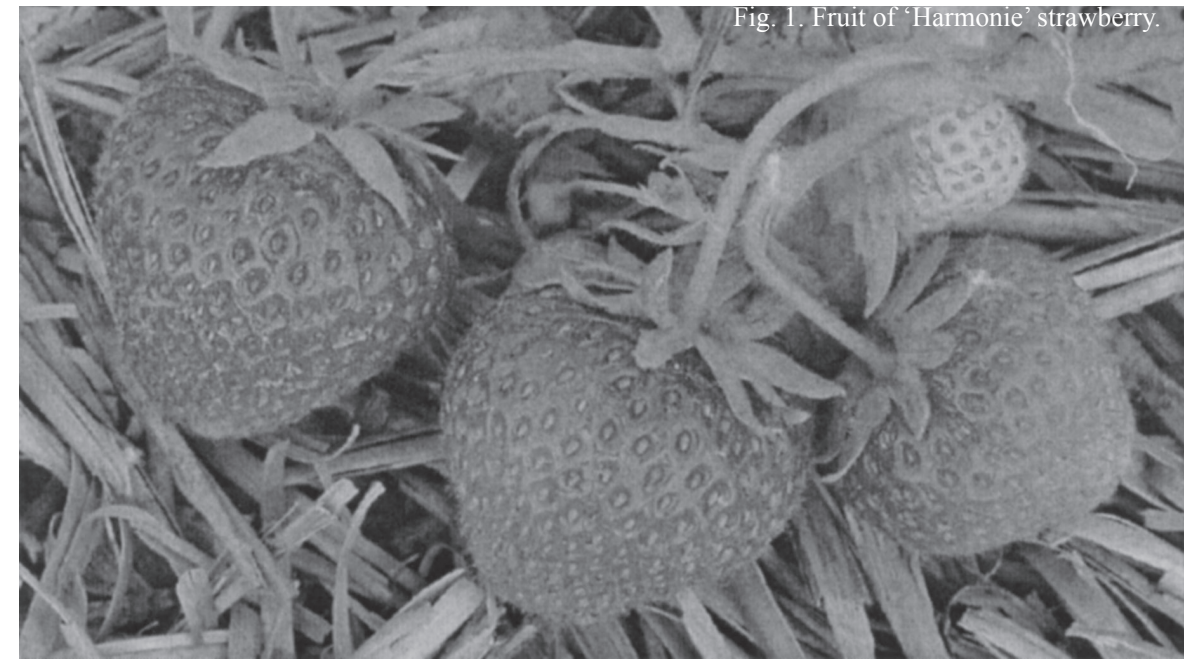

Fig. 2. Pedigree of 'Harmonie' strawberry.

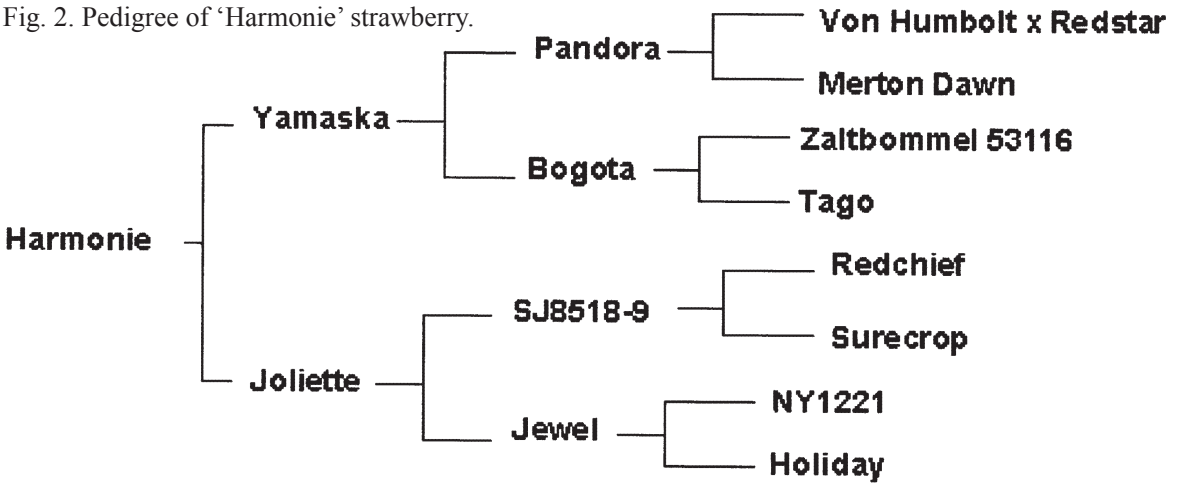


Table 1. Total yield, fruit weight and ripening season of 'Harmonie'strawberries vs. selected commercial genotypes at the L'Acadie experimental site, Quebec.

\begin{tabular}{lccc}
\hline Genotype & $\begin{array}{c}\text { Total yield } \\
\left(\mathrm{g} \cdot \mathrm{m}^{-1}\right)\end{array}$ & $\begin{array}{c}\mathrm{Wt} / \text { fruit }^{z} \\
(\mathrm{~g})\end{array}$ & $\begin{array}{c}\text { Ripening } \\
\text { season }^{y}\end{array}$ \\
\hline Yamaska & 1644.4 & 13.2 & $\mathrm{~L}$ \\
Kent & 2073.2 & 6.9 & $\mathrm{M}$ \\
Bounty & 2230.5 & 7.6 & $\mathrm{~L}$ \\
Harmonie & 2320.1 & 13.1 & $\mathrm{~L}$ \\
Chambly & 2379.5 & 7.3 & $\mathrm{EM}$ \\
Joliette & 2892.2 & 9.9 & $\mathrm{M}$ \\
Jewel & 2957.0 & 10.9 & $\mathrm{M}$ \\
Veestar & 3099.0 & 7.3 & $\mathrm{E}$ \\
Glooscap & 3460.2 & 7.4 & $\mathrm{M}$ \\
LSD & 410.0 & 1.6 & \\
\hline
\end{tabular}

${ }^{2}$ Averaged over 4 years from second year plantings (1999-2002), minimum of four replications per year, data taken from a 1-m-long representative portion of a 2-m matted row (width $50 \mathrm{~cm}$ ).

${ }^{\mathrm{y}} \mathrm{E}=$ early, $\mathrm{L}=$ late, $\mathrm{LM}=$ late-midseason, $\mathrm{M}=$ midseason, $\mathrm{EM}=$ early-midseason.

and 'Glooscap' (Table 1). 'Harmonie' is a late season cultivar and $50 \%$ of primary fruit are ripe by 4 July. 'Harmonie' has similar flavor to 'Bounty', 'Glooscap', and 'Kent' based on the informal taste panel (Table 2).

Total antioxidant capacity (trolox equivalent antioxidant capacity (TEAC) and the ferricreducing antioxidant power (FRAP)), total phenolics, and phenolic composition of the fruit were also evaluated according to procedures described previously by Gao et al. (2000), Tsao etal.(2003), and Slinkard and Singleton(1977), and using an HPLC method (Tsao and Yang,
2003), respectively. Phenolic compounds have been shown to have important functions in plant defense mechanisms (i.e., disease resistance and defense against several external stresses) and influence fruit quality and stability (storage) of foods by acting as flavorants, colorants or antioxidants (Maas et al., 1991).

The fruit of 'Harmonie' had a significantly higher FRAP and crude TEAC level, and contains a higher amount of total phenolics than 'Kent' (Table 3).

Berries were also high in hydroxycinnamic acids (23.9 ppm p-coumaric acid equivalent), benzoic acids (13.7 ppm gallic acid equivalent) and flavonols (7.5 ppm quercetin-3galactoside equivalent) than 'Kent' $(4,10.7$, and $4.2 \mathrm{ppm}$, respectively). The high total antioxidant content of 'Harmonie' fruit and freedom from symptoms of powdery mildew (Sphaerotheca macularis (Wallr. : Fr.) Lind.) and gray mold (Botrytis cinerea Pers. :Fr.) disease might be related. Lindhard Pedersen (2003) found that high levels of hydroxycinnamic acid derivatives were correlated with disease resistance in black currant. Benzoic acid is also known as a food preservative and might act as an antifungal agent to extend shelf life and as an antioxidant to enhance quality preservation (Baldwin et al., 1995). 'Harmonie' strawberry could be an important dietary source of antioxidants and their radical scavenging activity, which have been associated with lower mortality rates caused by cancer and heart diseases (Halliwell, 1997; Kalt et al., 1999).

Table 2. Sugar, acidity, firmness, flavor, skin color, leaf disease susceptibility, and shelf life of 'Harmonie' strawberries vs. selected commercial genotypes at the L'Acadie experimental site, Quebec. ${ }^{2}$

\begin{tabular}{lccccc}
\hline Genotype & Firmness $^{\mathrm{y}}$ & Flavor $^{\mathrm{y}}$ & $\begin{array}{c}\text { Skin } \\
\text { color }^{\mathrm{y}}\end{array}$ & $\begin{array}{c}\text { Leaf disease } \\
\text { susceptibility }\end{array}$ & $\begin{array}{c}\text { Shelf } \\
\text { life }^{\mathrm{x}}\end{array}$ \\
\hline Bounty & 2.4 & 3.0 & 3.0 & 3.0 & 1.0 \\
Glooscap & 2.8 & 3.1 & 3.8 & 2.8 & 1.0 \\
Kent & 3.1 & 3.0 & 2.8 & 1.3 & 2.0 \\
Harmonie & 3.3 & 3.0 & 2.5 & 3.8 & 5.0 \\
LSD & 0.4 & 0.7 & 0.3 & 0.7 & 2.1 \\
\hline
\end{tabular}

${ }^{\mathrm{z}}$ Averaged over 4 years from second year plantings (1999-2002), minimum of four replications per year data taken from a 1-m-long representative portion of a 2-m matted row (width $50 \mathrm{~cm}$ ).

${ }^{y}$ Data were transformed to arcsin (Steel and Torrie, 1980) before analysis of variance (SAS Inst., 1988). Firmness: $1=$ very soft, $5=$ very firm; flavor: $1=$ poor, $5=$ excellent; skin color: $1=$ very pale, $5=$ dark red; leaf disease susceptibility: 1 = very susceptible, 5 = resistant. See Khanizadeh et al. (1994) for details on score evaluations.

${ }^{x}$ Number of days at room temperature for which the fruit were $>95 \%$ marketable.

Table 3. Antioxidant capacity and total phenolic content of 'Harmonie' strawberries compared with 'Kent' one of the most popular genotype grown at L'Acadie experimental site, Quebec.

\begin{tabular}{|c|c|c|c|c|c|}
\hline \multirow[b]{3}{*}{ Genotype } & \multicolumn{4}{|c|}{ Total antioxidant capacity } & \multirow{3}{*}{$\begin{array}{c}\text { Content } \\
\text { Total phenols } \\
\text { (ppm) } \\
\text { Crude }\end{array}$} \\
\hline & \multicolumn{3}{|c|}{$\begin{array}{c}\text { TEAC }^{\mathrm{z}} \\
\left(\mu \mathrm{mol} \cdot \mathrm{mg}^{-1}\right)\end{array}$} & \multirow{2}{*}{$\begin{array}{l}\text { FRAPy }^{y} \\
(\mu \mathrm{M}) \\
\text { Crude }\end{array}$} & \\
\hline & Crude & Aqueous & $\overline{\text { Lipophilic }}$ & & \\
\hline Harmonie & 239.8 & 224.4 & 26.0 & 2752.2 & 142.8 \\
\hline Kent & 198.8 & 228.6 & 29.6 & 2131.5 & 106.1 \\
\hline LSD & 23.1 & 45.7 & 2.34 & 318.7 & 35.8 \\
\hline
\end{tabular}

${ }^{\mathrm{z}} \mu \mathrm{mol}$ Trolox equivalent per mg dry weight.

${ }^{y} \mu \mathrm{M}$ FRAP.

xppm Gallic acid equivalent.

\section{Areas of Adaptation and Uses}

'Harmonie' is recommended for Eastern Central Canada, especially in areas where the climate is similar to that in the strawberry production areas of Quebec. Typically, strawberry production in Quebec occurs in areas with winter temperatures down to $-30{ }^{\circ} \mathrm{C}$ and warm and humid summers with unpredictable mixture of sun and rain (drought some seasons, constant rain in other seasons).

\section{Availability}

A Canadian Plant Breeder's Right application is pending for 'Harmonie' and plants are available from licensed nurseries in Quebec. Nonexclusive multiplication licenses can be obtained from Agriculture and Agri-Food Canada. European nurseries can obtain a multiplication license from Meiosis Limited (Bradbourne House, Stable Block, East Malling, Kent ME19 6DZ). A limited number of plants are available for research purposes from the author (SK).

\section{Literature Cited}

Baldwin E.A., M.O. Nisperos-Carriedo, and R.A. Baker. 1995. Use of edible coatings to preserve quality of lightly processed products. Crit. Rev. Food Sci. Nutr. 35:509-24.

Gao, X., M. Ohlander, N. Jeppsson, L. Bjork, and V. Trajkovski. 2000. Changes in antioxidants effects and their relationship to phytonutrients of sea buckthorn (Hippophae rhamnoides L) during maturation. J. Agr. Food Chem. 48:1485-1490.

Halliwell, B. 1997. Antioxidants and human disease: A general introduction. Nutr. Rev. 55:44-52.

Kalt, W., C.F Forney.A. Martin, and R.L. Prior. 1999. Antioxidant capacity, vitamin C, phenolics, and anthocyanins after fresh storage of small fruit. J. Agr. Food Chem. 47:4638-4644.

Khanizadeh, S., J. Fortin, M.J. Lareau, and D. Buszard. 1994. Sensory evaluation of six strawberry cultivars after machine harvest, p. 249-254. In: H. Schmidt and M. Kellerhals (eds.). Progress in temperate fruit breeding. Kluwer Academic, The Netherlands.

L. Pedersen. 2003. http://www.darcof.dk/research/ darcofi/iil.html.

Maas, J.L., G.L. Galletta, and G.D. Stoner. 1991. Ellagic acid an anticarcinogen in fruit, especially in strawberries: A review. HortScience 26 (1):10-14.

SAS Institute. 1988. Statistical analysis system. SAS/ STAT, SAS/BASIC guide for personal computers. version 6.04 (ed.). SAS Inst., Cary, N.C.

Slinkard, K. and V.L. Singleton. 1977. Total phenol analysis: automation and comparison with manual methods. Amer. J. Enol. Viticult. 28:49-55

Steel, R.G.D. and J.H. Torrie. 1980. Principles and procedures of statistics. $2^{\text {nd }}$ ed. McGraw-Hill, New York.

Tsao, R. and R. Yang. 2003. Optimization of a new mobile phase to know the complex and real polyphenolic composition: Towards a total phenolic index using high-performance liquid chromatography. J. Chromatogr. Amer. 1018:29-40.

Tsao, R., R. Yang, and J.C. Yang. 2003. Antioxidant isoflavones in Osage Orange, Maclura pomifera (Raf.) Schneid. J. Agr. Food Chem. 51:6445-6451. 